Original Article

\title{
Anthropometric Analysis of Infraorbital Foramen in Adult Indian Dry Skull
}

\author{
Johncy Itty Panicker ${ }^{1}$, Vishal Kumar ${ }^{2} \&$ Vinay KumarVeerannasetty ${ }^{3}$ \\ ${ }^{1}$ M BBSStudent, ${ }^{3}$ Associate Professor, Department of Anatomy, K. S. Hegde M edical Academy, Nitte University, M angalore. \\ ${ }^{2}$ Professor \& HOD, Department of Anatomy, Kodagu Institute of M edical Sciences, M adikeri.
}

*Corresponding Author : Vishal Kumar, Professor \& HOD, Department of Anatomy, Kodagu Institute of M edical Sciences, Madikeri, Kodagu, Karnataka -571201. E-mail : vishalkumarmd@gmail.com

$\begin{array}{ll}\text { Received } & : \text { 01-07-2015 } \\ \text { Review Completed } & \text { : 08-03-2016 } \\ \text { Accepted } & : \text { 16-03-2016 }\end{array}$

Keywords : Infraorbital margin, Infraorbital nerve, Piriform aperture, Indian population, maxillofacial surgery.

\begin{tabular}{|c|}
\hline Access this article online \\
\hline Quick Response Code \\
\hline
\end{tabular}

\begin{abstract}
:
Introduction: Normally infra orbital foramen (IOF) is situated on the anterior surface of maxilla about $1 \mathrm{~cm}$ below the infra orbital margin (IOM) bilaterally. Infra orbital vessels and nerves emerge out through this foramen. Infra orbital nerve (ION) terminates by supplying skin over the lower eyelid, conjunctiva, lateral aspect of external surface of nose, upper lip, ala of the nose and the premolar teeth. Infra orbital vessels supply the area surrounding the IOF.
\end{abstract}

\begin{abstract}
Objective: To measure distance between superior part of the rim of the IOF to IOM (DIM) and the distance between the medial part of the rim of the IOF to lateral margin of the pyriform aperture (DIP). Compare the measurements of both sides. Compare our studies with other authors.
\end{abstract}

\begin{abstract}
Materials and methods: Sixty adult dry skulls of unknown sex were studied. Those skulls with damaged foramen were excluded. M easurementswere done in millimetres.

Result: The mean DIM on right side is $5.96 \mathrm{~mm}$ and on left side it is 6.07. M ean DIP on right side is $16.70 \mathrm{~mm}$ and on left side it is $16.63 \mathrm{~mm}$. We have observed that there is no much significant variations in respect to sides. Our values were within the range of many others value.
\end{abstract}

Conclusion: Knowing exact location of IOF using different land mark is important for providing local anaesthesia in maxillofacial, plastic surgical operations and radio ablative neurotomy procedures. Thus information obtained is very useful IOF to avoid iatrogenic injury in the infra orbital area.

\section{Introduction}

The infra orbital foramen (IOF) is situated on the anterior surface of maxilla about $1 \mathrm{~cm}$ below the infra orbital margin (IOM) bilaterally. Infra orbital vessels and nerves emerge out through $\operatorname{IOF}^{1}$. The Infra orbital nerve (ION) is a continuation of maxillary division of trigeminal nerve. It is entirely sensory in nature. It emerges out from IOF after passing through infra orbital canal and appears on the face. It terminates by dividing into palpebral, nasal and labial branches to supply skin over the lower eyelid, conjunctiva, lateral aspect of external surface of nose, upper lip, ala of the nose and the premolar teeth. Infra orbital vessels are branches of maxillary artery which supplies the area surrounding $\mathrm{IOF}^{2}$. Large variations in the location of IOF have been reported by many authors with regard to the different landmarks on the skull varying from 4- $12 \mathrm{~mm}^{3}$. Knowing the exact location of IOF is very important for giving local anesthesia in maxillofacial, plastic surgeries and radio ablative neurotomy procedures ${ }^{4}$. Zygomatic complex fractures are one of the most common facial injuries which involve $10 N^{5,6}$. In these cases, earlier the surgical intervention, more the recovery of the nerve injury ${ }^{7}$. A major factor that inhibits dentists from using the ION block is the fear of injury to the patient's eye ${ }^{3}$. Since there are very few studies done on the Indian population, the present study was undertaken.

\section{Materials and Method}

Sixty adult dry skulls of unknown sex were collected from the department of Anatomy. Those skulls with damaged 
foramen or fractures were excluded from the study. All the measurements were done in millimetres using a digital vernier caliper (M itutoyo Corp, Japan) with an accuracy of up to $0.1 \mathrm{~mm}$.

After placing the skull in anatomical position, the distance between superior parts of the rim of the IOF to IOM (DIM) in sagittal plane was measured (Fig. 1) and the distance between the medial parts of the rim of the IOF to lateral margin of the pyriform aperture (DIP) was measured in the horizontal plane (Fig. 1). All the readings were taken and the mean of the two were calculated on right and left side separately. All the measurements were tabulated and statistically analyzed for significance.

\section{Results}

The mean DIM on right side was between $3.2 \mathrm{~mm}$ to 10.42 $\mathrm{mm}$ and $2.6 \mathrm{~mm}$ to $10.1 \mathrm{~mm}$ on the left side (Table 1). The mean DIP on right side was between $10.1 \mathrm{~mm}$ to $22.7 \mathrm{~mm}$ and $8.3 \mathrm{~mm}$ to $23.1 \mathrm{~mm}$ on the left side. There was no statistically significant difference in the mean DIM \& DIP between the right and left side.

Fig. 1 : M easurements a) Distance between IOM and rim of IOF (A) b) Distance between PA and rim of IOF (B).

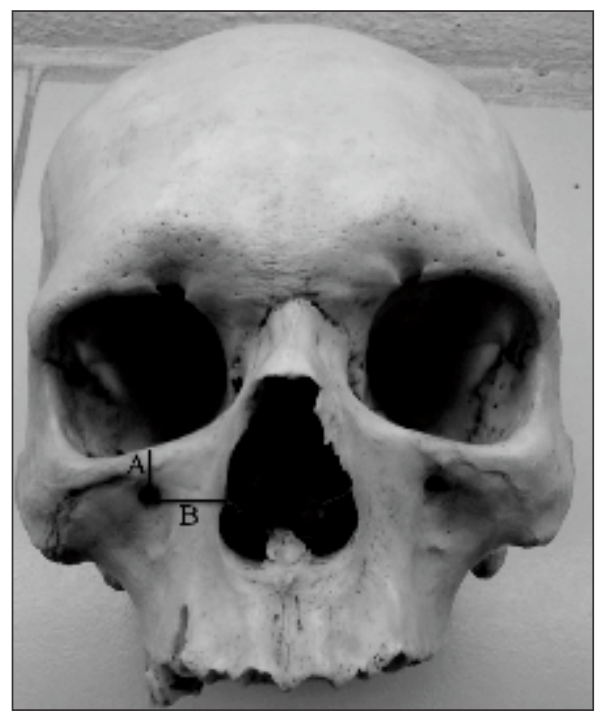

Table 1 : Mean DIM and DIP on right and left side.

\begin{tabular}{|l|c|c|}
\hline Side & DIM (mm) & DIP (mm) \\
\hline Right & 5.96 & 16.70 \\
\hline Left & 6.07 & 16.63 \\
\hline Both & 6.02 & 16.67 \\
\hline
\end{tabular}

\section{Discussion}

Table 2: Comparison of mean DIM between present study and the previousstudies.

\begin{tabular}{|l|c|c|c|}
\hline Study & $\begin{array}{c}\text { No. of } \\
\text { skulls }\end{array}$ & $\begin{array}{c}\text { Mean DIM } \\
\text { on right side } \\
\text { (M ean in } \\
\text { mm } \pm \text { SD) }\end{array}$ & $\begin{array}{c}\text { Mean DIM } \\
\text { on left side } \\
\text { (Mean in } \\
\text { mm } \pm \text { SD) }\end{array}$ \\
\hline Present Study 2014 & 60 & $5.96 \pm 1.59$ & $6.07 \pm 1.73$ \\
\hline Aziz et al. 2000 & 47 & $8.3 \pm 1.9$ & $8.1 \pm 1.9$ \\
\hline Elias et al. 2004 & 210 & $6.71 \pm 1.7$ & $6.83 \pm 1.83$ \\
\hline Agthong et al. 2005 & 110 & $7.8 \pm 0.2$ & $8.0 \pm 0.2$ \\
\hline M acedo et al. 2009 & 295 & $6.28 \pm 1.79$ & $6.45 \pm 1.76$ \\
\hline Lopes et al. 2009 & 99 & $6.57 \pm 1.70$ & $6.76 \pm 1.64$ \\
\hline Boopathi et al. 2010 & 80 & $6.49 \pm 1.26$ & $6.65 \pm 1.30$ \\
\hline Gour et al. 2010 & 100 & $6.52 \pm 1.79$ & $6.42 \pm 1.70$ \\
\hline Singh S, 2011 & 55 & $6.12 \pm 1.79$ & $6.19 \pm 1.81$ \\
\hline Bruno et al. 2011 & 80 & $6.30 \pm 1.67$ & $6.52 \pm 1.72$ \\
\hline Shaiket al. 2012 & 125 & $7.06 \pm 1.81$ & $7.20 \pm 1.71$ \\
\hline Lokanayaki, 2013 & 100 & $6.12 \pm 1.43$ & $6.53 \pm 1.53$ \\
\hline Elsheikh et al. 2013 & 59 & $6.12 \pm 1.4$ & $6.50 \pm 1.3$ \\
\hline
\end{tabular}

Table 3 : Comparison of the mean DIP of both sides between present and the previousstudies.

\begin{tabular}{|l|c|c|}
\hline Study & No. of skulls & Mean DIP (mm) \\
\hline Present Study 2014 & 60 & 16.67 \\
\hline Kaskayasi et al. 2001 & 35 & 14.31 \\
\hline Elias et al. 2004 & 210 & 13.29 \\
\hline M acedo et al. 2009 & 295 & 17.68 \\
\hline Singh S. 2011 & 55 & 15.56 \\
\hline Bruno et al. 2011 & 80 & 14.72 \\
\hline Shaiket al. 2012 & 125 & 18.13 \\
\hline Lokanayaki, 2013 & 100 & 16.48 \\
\hline
\end{tabular}

On comparison of mean DIM between the present and previous studies it was observed that the mean DIM was less than all the other studies. The data listed in the table. 2 are done in different regions and populations, like Brazil, India, Thailand, Egypt and different ethnic groups in New York. The studies done on Thai skulls ${ }^{8}$ and different ethnic groups in New York ${ }^{4}$ shows higher value than rest of the others. Our value is comparable with all the studies done in the region of Brazil ${ }^{9,10,11,12,}$ and India ${ }^{2,3,13,14}$ except a study done in southern part of India ${ }^{6}$ which shows higher value compared to ourstudy.

On comparison of the mean DIP of the present study with the previous studies, it was observed that the mean DIP of the present study was higher when compared to the data obtained by Elias MG et al. ${ }^{9}$ and Rajani Singh ${ }^{13}$ and lower 
when compared to the studies by HSShaik ${ }^{6}$ and M acedo VC et al ${ }^{10}$.

Lokanayaki, 2013 distance between rim IOF and PA, authors have shown quite wide variation ranging from 13 $\mathrm{mm}$ to $18 \mathrm{~mm}$ (Table. 3). Here the data listed in table. 3 are obtained from different geographical areas like Turkey, Brazil and India. In this our value is $16.67 \mathrm{~mm}$ which is comparable with one of the Indian study ${ }^{14}$.

The present results of this study provide valuable information to assist the maxillofacial surgeon to locating the infraorbital nerves and vessels. This will help to avoid damage to these structures ${ }^{15}$. Previous studies of different researchers have shown that distance between rim IOF and IOM are quite variable which are listed in table. 2. There are many surgical procedures are done over the maxilla such as rhinoplasty, Caldwell-Lucoperations, tumor surgery, reduction of the orbitalfloor (blow-out) and malar fractures, and the LeFort I type osteotomies may result in an iatrogenic injury to ION. Even in trigeminal neuralgia of second division knowledge of exact location of ION is essential to inject neurolytic solutions $s^{16,17}$.

The closest estimation of the location of the IOF should be used when designing access incisions to the orbital floor and rim and planning regional nerve blockade. However presence of multiple IOF should be kept in mind. Study quotes that higher frequency of multiple foramina was noted in M exicans ${ }^{4,18}$.

Nerve localization for this block ideally relies on a landmark-based approach using palpation of the foramina. However, occasionally it can be challenging to identify each foramen by relying on palpation alone. In these cases, many experts search for the foramina by gently probing with a small-gauge needle. Ultrasound imaging is a safe simple non-invasive modality through which soft tissues and nerve structures can be visualized and identified when combined with a thorough knowledge of regional

\section{References}

1. Standring S. Gray's Anatomy. $40^{\text {th }}$ ed, Churchill Livingstone Elsevier, New York. 2008.

2. Gaur KK, Nair S, Trivedi GN, Guptha SD. Anthropometric measurements of infraorbital foramen in dried human skulls. Int J anatomy ${ }^{19}$.

Infra orbital nerve blocks are performed in children for management of postoperative pain associated with cleftlip surgery and endoscopic sinus surgery. The main aspect in determining the placement of the needle is to locate the IOF and to access the nerve through an intraoral route or through a transcutaneous route ${ }^{20}$.

ION sensory disturbances are diagnosed based on patients' symptoms, which includes hyperalgesia or hypoalgesia of the skin. Hyperalgesia was diagnosed in $11.9 \%$ of patients and hypoalgesia in $52.5 \%$ of patients. ${ }^{5}$. Hu SH et al., described the areas supplied by the different branches of $\mathrm{ION}^{21}$.

Locating and preserving the infra orbital neurovascular bundle can be difficult with a comminuted fractureof the anterior maxillary wall and inferior orbital rim. The data show only small significant differences between males and females. Therefore, knowledge of the distance from the inferior orbital rim may be valuable in identifying the danger zone of its location during dissection of these fractures as well as during other surgical procedures ${ }^{15}$.

Studies conducted in different geographical areas showed a large dispersion and variability in the various distances pertaining to the location of the IOF due to different osteoblastic and osteoclastic activity in different individual $\mathrm{s}^{13}$.

\section{Conclusion}

Thus, the data obtained in this study is at par with studies conducted by different authors of various geographical areas. So the information derived here in identifying the precise location IOF will help surgeons to reduce the adverse outcome of the surgeries centered on IOF in patients of Indian origin. This information is also useful for morphologists who conduct their research on people of different populations and geographical regions.

Biol M ed Res 2012; 3(3): 2003-2006.

3. Boopathi S, Chakravarthy MS, Dhalapathy S, Anupa S. Anthropometric analysis of the infraorbital foramen in a South Indian population. Singapore M ed J 2010; 51(9): 730-735. 
4. Aziz SR, Marchena JM, Puran A. Anatomic characteristics of the infraorbital foramen: a cadaver study. J Oral M axillofacSurg 2000; 58: 992-996.

5. Sakavicius D, Juodzbalys G, Kubilius R, Sabalys GP. Investigation of infraorbital nerve injury following zygomaticomaxillary complex fractures. Journal of Oral Rehabilitation 2008; 35: 903-916.

6. Shaik HS, Shepur M P, Desai SD, Thomas ST, M aavishettar GF, Haseena $\mathrm{S}$. Morphometric analysis of Infra orbital foramen position in south Indian skulls. Indian J Innovations Dev 2012; http://iseeadyar.org /ijid.html

7. Kumar P, Godhi S, Lall AB, Ram CS. Evaluation of Neurosensory Changes in the Infraorbital Nervefollowing Zygomatic Fractures. J M axillofac Oral Surg 2012; 11(4): 394-399.

8. Agthong S, Huanmanop T, Chentanez V. Anatomical Variations of the Supraorbital, Infraorbital, and Mental Foramina Related to Gender and Side 2005; J Oral M axillofacSurg, 63: 800-804.

9. Elias M G, Silva RB, Pimentel ML, Cardoso VTS, Rivello T, Babinski MA. Morphometric analysis of the infraorbital foramen and acessoriesforaminas in brazilian skulls. Int J M orphol 2004; 22(4): 273278.

10. Macedo VC, Cabrini RR, faig-leite H. Infraorbital foramen location in dry human skulls. BrazJ M orphol Sci 2009; 26(1): 35-38.

11. Lopes PTC, Pereira GAM, Santos AMPV, Freitas CR, Abreu BRR, Malafaia AC. Morphometric analysis of the infraorbital foramen related to gender and laterality in dry skulls of adult individuals in southern Brazil. BrazJ M orpholSci 2009; 26(1): 19-22.

12. Chrcanovic BR, Nogueira MH, Abreu G, Custo'dio ALN. A morphometric analysis of supraorbital and infraorbital foramina relative to surgical landmarks. Surg Radiol Anat 2011; 33: 329-335.

13. Singh R. Morphometric analysis of infraorbital foramen in Indian dry skulls. Anat Cell Biol 2011; 44:79-83

14. Lokanayaki V. Anatomic variations of infra orbital foramen. CIBTech Journal of Surgery 2013; 2 (2): 30-36.

15. Cutright B, Quillopa N, Schubert W. An anthropometric analysis of the key foramina for maxillofacial surgery. J Oral M axillofacSurg 2003; 6: 354-357.

16. Kazkayasi M, Ergina, Ersoy M, Tekdemir I, Elhan A. Microscopic anatomy of the infraorbital canal, nerve, and Foramen. Otolaryngology -- Head and Neck Surgery 2003; 129 (6): 692-697.

17. Saraladevi KV, Udhaya K, Shastri D. Infraorbital Foramen in South Indian Population: Anthropometric M easurements and Their Clinical Relevance. IJBM S2014; 5 (1) ISSN- 0976-3554.

18. Tezer M, Öztürk A, Akgül M, Gayretli Ö, Kale A. Anatomic and morphometric features of the accessory infraorbital foramen. J M orphol Sci 2011; 28(2): 95-97.

19. Tsui $\mathrm{BCH}$. Ultrasound imaging to localize foramina for superficial trigeminal nerve block.J Can Anesth 2009; 56:704-706.

20. Suresh S, Polina V, John C. Infraorbital Nerve Block in Children: A Computerized Tomographic Measurement of the Location of the Infraorbital Foramen. Regional Anesthesia and Pain M edicine 2006; 